\title{
THE GROUND BEAN AND THE BEAN MOUSE AND THEIR ECONOMIC RELATIONS
}

\author{
By Melvin Randolph Gilmore, Ph.D.,
}

Curator of the State Historical Society of North Dakota

There is a native wild bean found growing over an area of wide distribution in North America. The botanical name of this bean is Falcata comosa. In the Dakota language it is called maka ta omnicha, which means "bean of the earth"; in the Pawnee language it is called ati-kuraru, which means "earth bean." The plant grows in dense masses over shrubbery and other vegetation in some places, especially along banks and at the edge of timber.

It forms two kinds of branches, bearing two forms of flower, producing two forms of fruit. Leafy branches climb up over the shrubbery, but under these, in the shade, prostrate on the earth, starting out from the base of the main stem, are leafless, colorless branches, forming a network on the surface of the ground. The tiny, inconspicuous blossoms borne on these prostrate branches are self-pollinated and push into the leafmold and soft soil and there each produces a single large bean closely clothed by a thin, filmy pod or husk. These beans which are formed in the earth are about the size of Lima beans. Upon the upper, leafy branches are borne showy, purplish flowers appearing like small bean blossoms. From these blossoms are produced small bean pods about a half inch to an inch in length. These pods contain each from three to four or five small, hard, mottled beans about an eighth of an inch long.

The large beans produced in the ground are desirable for food. They are of good flavor when cooked. The small beans of the upper branches are also good for food, but they are so small and difficult to harvest that not much use is made of them by the people. The large beans formed in the earth would also be hard to gather but for the help of certain little animals called voles, or wood mice, or bean mice. The voles dig the large beans and store them in considerable quantities in storage places which they hollow out in the ground and which they cover 
with sticks and leaves and earth. In these places the little animals put away sometimes a peck or a half bushel of beans. The scientific name of the bean mouse is Microtus pennsylvanicus. .

Throughout all the extensive range of Falcata comosa, the ground bean, it was sought by the people of the various Indian tribes to add to their food supply. The people said they did not take away all the beans from the voles as it would be wicked to loot the animals' food stores and leave the animals to starve after they had worked to gather them. But they would take a part of the store, in a manner making themselves beggars to the little animals. The Omahas have a saying that "The bean mouse is a very industrious fellow, he even helps human beings."

But in all accounts $I$ have had from the people of the Dakota nation the women have always said that they never took away any beans from the voles without making some payment in kind. They said it would be wicked and unjust to take the beans from the animals and give nothing in return. So they said they always put back some corn, some suet, or some other food material in exchange for the beans they took out. In that way they said both they and the little animals obtained a variety in their food supply. They said they thought it very wrong to deprive the animals of their store without such payment, but that it was fair if they gave a fair exchange.

The people of the Dakota nation speak of the wood mice or voles by the designation of "Hintunka people." In the Dakota theory of the universe they personify the maternal power and spirit by the name Hunka. Hunka is the mystic All-Mother in nature, the mother of all living beings, plant or animal, which, of course, includes mankind. For they do not think of mankind as being apart from nature and the community of life in the world.

The Dakota have a moral story which is told as follows:

A certain woman went and plundered the storehouse of some Hintunka people. She robbed them of their entire food supply without even giving them anything at all in return. The next night this woman who had robbed the Hintunka people of all their food supply heard a woman down in the woods crying and saying, "Oh, what will my poor children do?" It was the voice of one of the Hintunka women crying over her hungry children. 
The same night the woman who had done the wrong had a dream. In her dream Hunka appeared to her and said, "You should not have taken the food from the Hintunka people. Take back the food to them, or else your own children shall cry for food."

The next morning the woman told her husband what Hunka had said to her. Her husband said, "You would better do as Hunka tells you to do." But the woman was hard-hearted and perverse and would not restore to the Hintunka people the food of which she had robbed them, neither would she give them anything in exchange.

A short time after this a great prairie fire came; driven by a strong wind, and swept over the place where this unjust woman and her family were camping. The fire burned up her tepee and everything it contained, and they barely escaped with their lives. They had no food nor shelter and they had to wander on the prairie destitute.

The bean mouse and its works are regarded with respect, admiration and reverence by the people of the various Indian tribes which benefit by its labor. 'They feel very resentful towards any seeming tendency to meddle unwarrantedly with the winter storehouses of the vole. Upon hearing of the desire of a white man to make a photograph of such a storehouse an old man of the Teton-Dakota on the Standing Rock Reservation expressed bitter resentment and declared himself ready to fight to prevent such a thing from being done. He said "We have enough misfortune already, counting the war and the epidemic of influenza, without inviting further disaster by such sacrilege."

. In the month of November, after the voles have harvested their beans and laid them up in their storehouses for the winter, the people often go out alone and sit near some such storehouse in silent meditation on the ways of Providence. At that time of year missionaries and priests are often pained and puzzled because of the absence of some of their church members from Sunday service or from mass on Sunday morning. They do not know, and likely would not appreciate or understand the feeling which has caused these people to go out at such a time, not to the church but out to the quiet place under the open heaven where they sit upon the lap of Mother Earth to reverently and thankfully meditate upon the mysteries of nature and the wonderful provisions of God in nature.

At such times they like to bring in to their homes or to their churches some object connected with the bean mouse and his marvelous ways and work. If they find some beans which the 
vole has spilled in transportation to his storehouse, or a tree leaf which the bean mouse has used as his sled for carrying his loads from field to storehouse, they will bring in such objects and lay them up reverently in the home or in the church with devout regard for prayerful meditation. Indians say that the vole uses a leaf of the boxelder tree, or sometimes another kind of a leaf of suitable shape, as a sled for gathering his stores.

At one time an old blind man of the Teton-Dakota on the Standing Rock Reservation on the upper Missouri River went out to the vicinity of a vole's storehouse to meditate and pray. A man saw him and quietly approached within hearing distance. As the old man was blind he did not perceive the approach of the observer. Thinking himself alone in the presence of the powers of nature, this devout old man, gave expression to his religious feeling in the following prayer:

"Thou who art holy, pity me and help me pray. Thou art small, but thou art sufficiently large for thy place in the world. And thou art sufficiently strong also for thy work, for Holy Wakantanka constantly strengthens thee. Thou art wise, for the wisdom of holiness is with thee constantly. May I be wise in all my heart continually, for if an attitude of holy wisdom leads me on, then thịs shadow-troubled life shall come into constant light." 
Copyright of Annals of Iowa is the property of State of Iowa, by \& through the State Historical Society of Iowa and its content may not be copied or emailed to multiple sites or posted to a listserv without the copyright holder's express written permission. However, users may print, download, or email articles for individual use. 